\title{
TRUE ANEURYSM OF TEMPORAL SUPERFICIAL ARTERY ARISE SPONTANEOUSLY. CASE REPORT
}

Aleksandar Janicijevic ${ }^{1}$, Anica Jevremovic ${ }^{2}$, Vojin Kovacevic ${ }^{3}$, Vuk Scepanovic ${ }^{1}$, Ivan Bogdanovic ${ }^{1}$, Nikola Repac ${ }^{1}$, Igor Djoric ${ }^{4}$ and Goran Tasic ${ }^{1,2}$ ${ }^{1}$ School of medicine, University of Belgrade, Belgrade, Serbia

${ }^{2}$ Clinic for neurosurgery, Clinical center of Serbia, Belgrade, Serbia

${ }^{3}$ Department of Surgery, Faculty of medical sciences University of Kragujevac, Kragujevac, Serbia

${ }^{4}$ Department of Radiology, Clinical center of Serbia, Belgrade, Serbia

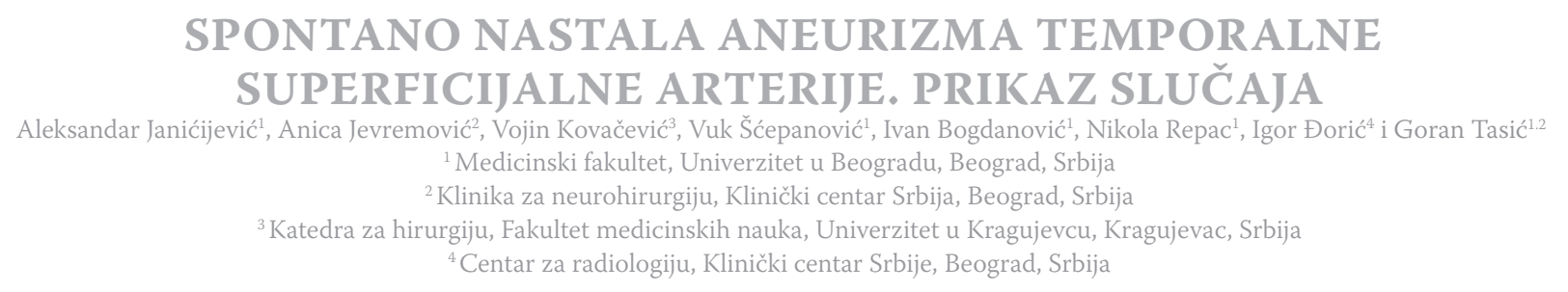

Received / Primljen: 26. 04. 2017.

Accepted / Prihvaćen: 07. 07. 2017.

\begin{abstract}
Aneurysms of the temporal superficial artery (TSA) are very rare clinical entity. From 1861 to the present day, is described less than 200 cases. The most common cause of these aneurysms is so called blunt head trauma but there are described many cases of iatrogenic aneurysms, very rarely, aneurysms arise spontaneously. We report a case of 17-yearold patient with spontaneously formatting aneurysm of TSA. Three months prior to admission, he noticed the existence of tumefaction localized frontotemporal on the right side. MSCT angiography of blood vessels of the scalp showed an aneurysm on the frontal branch of TSA diameter of $15 \mathrm{~mm}$. The aneurysm was resected with uneventful postoperative course. PH findings pointed to a true aneurysm. Treatment protocol for the aneurysms of the TSA include clinical monitoring, compression of the aneurysm, the injection of thrombin, endovascular treatment and surgical resection. Surgical resection has proven to be a safe and effective treatment modality and still is the method of choice.
\end{abstract}

Keywords: aneurysm, temporal superficial artery

\section{SAŽETAK}

Aneurizme temporalne superficijalne arterije (TSA) su vrlo retke. Od 1861. godine do danas je opisano manje od 200 slučajeva. Najčešci uzrok nastanka ovih aneurizmi su tupe povrede glave, ali je opisan i veliki broj aneurizmi jatrogene etiologije, dok su spontano nastale aneurizme još ređe. Opisali smo slučaj pacijenta muškog pola, starog 17 godina, kod kojeg je dijagnostikovana sponatno nastala aneurizma TSA. Tri meseca pre hospitalizacije, pacijent je primetio postojanje tumefakcije u čeonoslepoočnoj regiji sa desne strane. MSCT angiografija krvnih sudova poglavine je ukazala na aneurizmu čeone grane TSA dijametra $15 \mathrm{~mm}$. Aneurizma je hirurški eksicidirana, postoperativni tok je uredno protekao. Patohistološka analiza je pokazala da se radi o pravoj aneurizmi. Protokol za zbrinjavanje TSA aneurizmi podrazumeva kliničko praćenje, kompresiju aneurizme, injekciju trombina, endovaskularni tretman i hiruršku resekciju. Hirurška resekcija se pokazala kao siguran i efikasan modalitet lečenja $i$ još uvek je metoda izbora.

Ključne reči: aneurizma, temporalna superficijalna arterija

\section{ABBREVIATIONS}

MRI - Magnetic resonance imaging MSCT - Multislice computed tomography
PH - Patohistology

TSA - Temporal superficial artery

\section{INTRODUCTION}

Temporal superficial artery (TSA) is the terminal branch of the external carotid artery from that usually separates behind the angle of the mandible. It has two terminal branches, frontal and parietal. Aneurysms of the TSA are rare clinical entity. Thomas Bartholin has published the case of a young patient who had blunt head trauma and who has aneurysms on the TSA in 1740 (1).

From 1861 to the present day is described less than 200 cases $(2,3)$. Indications for treatment of aneurysms of the
Corresponding author: Vojin Kovačević, Center for Neurosurgery, Clinical Center of Kragujevac, Zmaj Jovina street, 34000 Kragujevac, Serbia, e-mail:vojinkg@gmail.com Tel. / 069-609144 
TSA are headache, aesthetic reasons, and most importantly the prevention of aneurysm rupture or erosion of bone.

The most common cause of these aneurysms is so called blunt head trauma but there are described many cases of iatrogenic aneurysms, very rarely, aneurysms arise spontaneously.

We report a case of 17-year-old patient with spontaneous aneurysm of TSA.

\section{CASE REPORT}

Male patient 17 years old noticed the existence of tumefaction localized on the right side of forehead three months prior to admission. He thought that the change is an atheroma and has not been to a medical examination. After two and a half months, the patient noticed that the change is increased in size and it became painfully sensitive to touch. Then he reported to our clinic.

By physical examination, we found pulsating palpatory painfully sensitive tumefaction measuring $1 \times 2 \mathrm{~cm}$. Flank mass was mobile in relation to the bone. MSCT angiography of blood vessels of the scalp showed an aneurysm on the frontal branch of TSA (Figure 1).

After preoperative evaluation, the patient was operated. The aneurysm was resected and the postoperative course was uneventful. The patient was discharged home the next day. Control MSCT angiography of blood vessels of the scalp showed absence of vascular anomalies. Sutures are removed 7 days after the surgery. $\mathrm{PH}$ findings pointed to a true aneurysm. In the period of fourth months of follow up, there were no signs of recurrence.

\section{DISCUSSION}

Aneurysms of TSA is rarely seen. So far is described less than 200 cases of these aneurysms which are solitary in most cases, but sometimes can be multiple $(4,5)$. In $89 \%$ percent of reported cases were pseudo aneurysms, while the remaining $11 \%$ were true aneurysms of TSA (1). Pseudo aneurysms usually occur after blunt head trauma in $75 \%$ of cases $(6,7)$. The most commonly occur on the front branch of TSA because of its anatomical position. The frontal branch of TSA pass over upper temporal line where is the junction between frontal and temporal muscle and arteries passing through the hole between the two muscles and remains unprotected (8). Apart from blunt trauma to the head, there are also described cases of aneurysm formation after firearms injuries $(9,10)$.

Also, a certain percentage of pseudo aneurysms occurs iatrogenic after bypass surgery (11) after craniotomy (12), after a hair transplantation (13) and even as a complication of Botox injections (14). True aneurysms occur mainly spontaneously (15). Causes of it still is not completely understood. It is assumed that atherosclerotic changes may have important influence on the spontaneous occur-

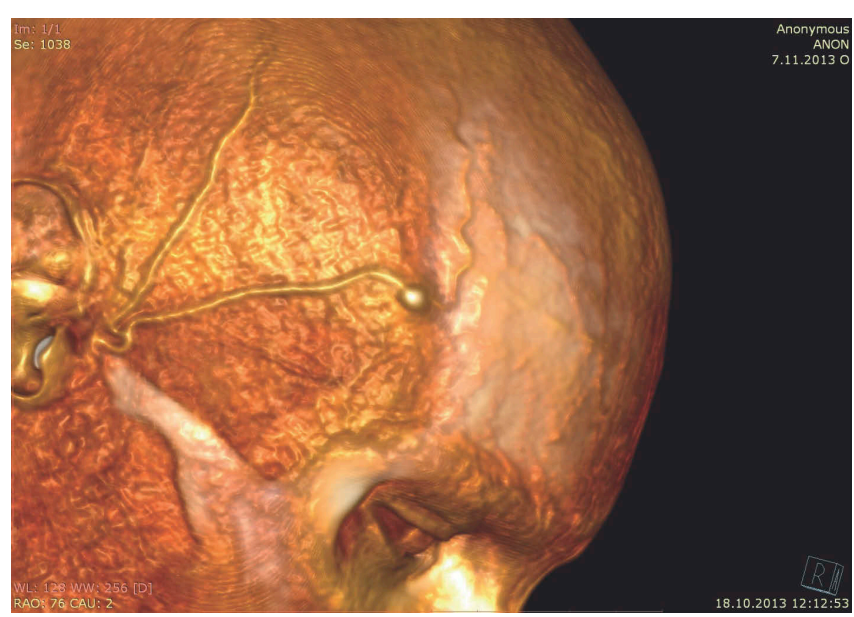

Figure 1. MSCT angiography of scalp blood vessels

rence of true aneurysms (16). In addition, given that the true aneurysms occur in younger patients, it must be assumed that there are other causes. According to some authors congenital defect of the vessel wall also has a role in the development of true aneurysms, as well as segmental arteriopathic amyloidosis (17) or non-specific temporal arteritis (5). Differentiation whether it is a true or pseudo aneurysms is only possible by histopathological analysis.

Aneurysms of TSA is usually first suspected after physical examination. It is usually presented as a subcutaneous non adhesive pulsating mass whose pulsations coincide with the pulsations of blood pressure. The use of duplex ultrasound can help in the diagnosis (18). Native CT scan and MRI exam can be used in diferential diagnosis purposes to preclude the existence of fistula of medial meningeal artery (19). According to the review of the literature, some authors have used the DS angiography of blood vessels. By their opinion that accurate preoperative identification of afferent vessels accelerates and facilitates the identification of the aneurysm and its surgical excision (20). From our point of view, and according to other authors (1) the DSA is an invasive procedure and carries a minimum, but still existing, risk of stroke, dissection of intima of the vessels and bleeding, and as such is unusefull for this type of pathology. It is much safer and yet extremely illustrative 3D MSCT angiography (21) that we used in this case.

Unlike degenerative aneurysms of TSA, which are increased gradually over the time, traumatic aneurysms are usually increased rapidly over a period of 1 to 6 weeks after the trauma (22). The natural course of the disease is in most cases the rupture, rarely thrombosis.

In the treatment of aneurysms of TSA can apply conservative and radical methods. Treatment protocol for the aneurysms of the TSA include clinical monitoring, compression of the aneurysm, the injection of thrombin, endovascular treatment and surgical resection. Edwards M. R. published the first conservative treatment method for the aneurysm of TSA in 1861. The patient was student who was pressing the aneurysm and caused spontaneous thrombosis (4). Most of the patients, according to the 
literature, underwent surgical resection of the aneurysm (23 - 25), which proved to be a safe and effective treatment. Still, there were described complications of surgery in the form of postoperative paresis n. VII $(13,26)$ and $n$. XII (most likely mobilization of the upper portion of the extenal carotid artery to be correlated to stretching of the nerve during the surgery) (23). Also, some authors for the treatment of aneurysms of the TSA suggest direct puncture and injection of thrombin with ultrasound navigation $(27,28)$. The disadvantage of this method is that it is difficult to control the dispersion of thrombin, which can lead to necrosis of the flap (29).

Standard endovascular intervention of coiling aneurysms $(30,31)$ may be an alternative to surgical resection in some cases and that in the case of aneurysms in the facial region. Still the potential embolic complications represent a significant limitation of this method. Some authors have used direct percutaneous coiling embolization of aneurysms guided by ultrasound (32).

\section{CONCLUSION}

Aneurysms of the TSA are rare clinical entity. Indications for treatment of aneurysms of the TSA are headache, aesthetic reasons, and most importantly the prevention of aneurysm rupture or erosion of bone. Protocol treatment of aneurysms of TSA include clinical monitoring, compression of the aneurysm, the injection of thrombin, endovascular treatment and surgical resection. Surgical resection has proven to be a safe and effective treatment modality and it is the method of choice. In some cases, need to think about injections of thrombin or endovascular treatment.

\section{REFERENCES:}

1. DeSanti L. Aneurysms of the temporal region. Arch Gen Med 1884; 154: 543-679.

2. Conner WC III, Rohrich RJ, Pollock RA. Traumatic aneurysms of the face and temple: a patient report and literature review, 1644 to 1998. Ann Plast Surg 1998; 41: 321-326.

3. Dominique van U, Maarten T, Ellis S, Clark Michel R. Superficial temporal artery aneurysm: Diagnosis and treatment options. Head \& Neck 2013; 35: 608-613.

4. Edwards MR. Aneurysm of the temporal artery: cure by compression. Lancet 186; 2: 135.

5. Yoshimoto T, Kobayashi H, Murai H, Echizenya K, Satoh M. Multiplescalp aneurysms caused by atypical temporal arteritis-case report. Neurol Med Chir (Tokyo) 1998; 38: 405-408.

6. Bole PV, Munda R, Purdy RT, Lande A, Gomez R, Clauss RH. Traumatic pseudoaneurysm: a review of 32 cases. J Trauma 1976; 16: 63-70.

7. Shenoy SN, Raja A. Traumatic superficial temporal artery aneurysm. Neurol India 2003; 51: 537-538.
8. Han K, Borah GL. Pseudoaneurysm of the anterior superficial temporal artery. Ann Plast Surg 1996; 37: 50-53.

9. Amirjamshidi A, Abbassioun K, Rahmat H. Traumatic aneurysms and arteriovenous fistulas of the extracranial vessels in war injuries. Surg Neurol 2000; 53: $136-145$.

10. Weller CB, Reeder C. Traumatic pseudoaneurysm of the superficial temporal artery: two cases. J Am Osteopath Assoc 2001; 101: 284-287.

11. Kurokawa T, Harada K, Ishihara H, Fujisawa H, Kato S, Kajiwara K, Suzuki M. De novo aneurysm formation on middle cerebral artery branches adjacent to the anastomotic site of superficial temporal artery-middle cerebral artery. Neurosurgery 2007; 61: 297-298.

12. Angevine PD, Connolly ES Jr. Pseudoaneurysms of the superficial temporal artery secondary to placement of external ventricular drainage catheters. Surg Neurol 2002; 58: 258-260.

13. Murphy M, Hughes D, Liaquat I, Edmondson R, Bullock P. Giant traumatic pseudoaneurysm of the superficial temporal artery: treatment challenges and case review. Br J Neurosurg 2006; 20: 159-161.

14. Ghassan S, Nathalie D, Joseph S, Bishara A. Pseudoaneurysm of the Superficial Temporal Artery: A Complication of Botulinum Toxin injection. Aesth Plast Surg 2012; 36: 982-985.

15. Kawabori M, Kuroda S, Nakayama N, Kenmotsu Y, Shimizu H, Tanino M, Iwasaki Y. Spontaneous giant aneurysm of the superficial temporal artery: case report. Neurol Med Chir (Tokyo) 2009; 49: 198-201.

16. Endo T, Mori K, Maeda M. Multiple arteriosclerotic fusiform aneurysms of the superficial temporal artery-case report. Neurol Med Chir (Tokyo) 2000; 40: $321-323$.

17. Ohta H, Sakai H, Nakahara I, Sakai N, Nagata I, Ishibashi-Ueda H. Spontaneous superficial temporal artery aneurysm associated with multipleintracranial cerebral aneurysms - does it segmental mediolytic arteriopathyof the intra - and extra-cranial arteries. Acta Neurochir (Wien) 2003; 145: 805-806.

18. Goksu E, Senay E, Alimoglu E, Aksoy C. Superficial temporal artery.

19. Nishioka T, Kondo A, Aoyama I, Nin K, Shimotake K, Tashiro H, Takahashi J, Kusaka H. A case of spontaneous superficial temporal artery aneurysm. No Shinkei Geka 1988; 16: 1009-1012.

20. Walker MT, Liu BP, Salehi SA, Badve S, Batjer HH. Superficial temporal artery pseudoaneurysm: diagnosis and preoperative planning with CT angiography. AJNR Am J Neuroradiol 2003; 24: 147-150

21. Mattens M, Hessmann M, Lesceu O, Rumbaut J. Traumatic false aneurysm of the superficial temporal artery. Acta Chir Belg 1992; 92: 201-203

22. Fox JT, Cordts PR, Gwinn BC 2nd. Traumatic aneurysm of the superficial temporal artery: case report. J Trauma 1994; 36: 562-564 
23. Pseudoaneurysm: ultrasonographic diagnosis in the ED. Am J Emerg Med 2009; 27: 627.

24. Jimenez JC, Nassoura Z, Morris LF, Hu D. Late traumatic aneurysm of the superficial temporal artery. J Vasc Surg 2011; 54: 1174.

25. Sakamoto T, Sugimoto M, Kakigi A, Iwamura H, Kashio A, Suzuki M, Yamasoba T. A spontaneous true aneurysm of the superficial temporal artery treated by surgical resection. Auris Nasus Larynx. 2011; 38: 119-122

26. Lalak NJ, Farmer E. Traumatic pseudoaneurysm of the superficial temporal artery associated with facial nerve palsy. J Cardiovasc Surg (Torino) 1996; 37: 119-123

27. Bobinski L, Bostrom S, Hillman J, Theodorsson A. Postoperative pseudoaneurysm of the superficial temporal artery (S.T.A.) treated with Thrombostat (thrombin glue) injection. Acta Neurochir (Wien) 2004; 146: 1039-1041
28. Partap VA, Cassoff J, Glikstein R. US-guided percutaneous thrombin injection: a new method of repair of superficial temporal artery pseudoaneurysm. J Vasc Interv Radiol 2000; 11: 461-463

29. Teh LG, Sieunarine K. Thrombin injection for repair of pseudoaneurysms: a case for caution. Australas Radiol 2003; 47: 64-66

30. Hong JT, Lee SW, Ihn YK, Son BC, Sung JH, Kim IS, Kim IS, Kim MC. Traumatic pseudoaneurysm of the superficial temporal artery treated by endovascular coil embolization. Surg Neurol 2006; 66: 86-88

31. Komiyama M, Nakajima H, Nishikawa M, Yasui T. Endovascular treatment of traumatic aneurysms of the superficial temporal artery. J Trauma 1997;43:545-548

32. Gulati MS, Gupta H, Sharma S, Kapoor V, Paul S, Berry M. Direct percutaneous coil embolization of a pseudoaneurysm under color Doppler guidance. Cardiovasc Intervent Radiol 1999; 22: 265-266 